\title{
8-Alkylcoumarins from the Fruits of Cnidium monnieri Protect against Hydrogen Peroxide Induced Oxidative Stress Damage
}

Chi-I Chang ${ }^{1}$, Wan-Chiao Hu ${ }^{2}$, Che-Piao Shen ${ }^{3,4}$, Ban-Dar Hsu ${ }^{3}$, Wei-Yong Lin ${ }^{5, *}$, Ping-Jyun Sung ${ }^{6,7}$, Wei-Hsien Wang ${ }^{7,8}$, Jin-Bin $\mathrm{Wu}^{9}$ and Yueh-Hsiung Kuo ${ }^{10,11, *}$

1 Department of Biological Science and Technology, National Pingtung University of Science and Technology, Pingtung 912, Taiwan; E-Mail: changchii@mail.npust.edu.tw

2 Department of Chemistry, National Taiwan University, Taipei 106, Taiwan; E-Mail: r93223083@ntu.edu.tw

3 Institute of Bioinformatics and Structural Biology, National Tsing Hua University, Hsinchu 300, Taiwan; E-Mails: d918214@oz.nthu.edu.tw (C.-P.S.); bdhsu@life.nthu.edu.tw (B.-D.H.) Department of Medical Research, China Medical University Hospital, Taichung 404, Taiwan

5 Graduate Institute of Integrated Medicine, China Medical University, Taichung 404, Taiwan

6 Graduate Institute of Marine Biotechnology and Department of Life Science and Institute of Biotechnology, National Dong Hwa University, Pingtung 944, Taiwan;

E-Mail: pjsung@nmmba.gov.tw

7 National Museum of Marine Biology and Aquarium, Pingtung 944, Taiwan;

E-Mail:whw@mail.nsysu.edu.tw

8 Department of Marine Biotechnology and Resources, National Sun Yat-sen University, Kaohsiung 804, Taiwan

9 Graduate Institute of Pharmaceutical Chemistry, China Medical University, Taichung 404, Taiwan; E-Mail: jbwu@mail.cmu.edu.tw

10 Department of Chinese Pharmaceutical Sciences and Chinese Medicine Resources, China Medical University, Taichung 404, Taiwan

11 Department of Biotechnology, Asia University, Taichung 413, Taiwan

* Authors to whom correspondence should be addressed;

E-Mails: kuoyh@mail.cmu.edu.tw (Y.-H.K.); linwy@mail.cmu.edu.tw (W.-Y.L.); Tel.: +886-4-2205-3366 (ext. 5701) (Y.-H.K.); Fax: +886-4-2207-1693 (Y.-H.K.).

Received: 10 December 2013; in revised form: 13 February 2014 / Accepted: 6 March 2014 / Published: 17 March 2014

Abstract: Three new 8-alkylcoumarins, 7-O-methylphellodenol-B (1), 7-methoxy-8-(3-methyl2,3-epoxy-1-oxobutyl)chromen-2-one (2), and 3'-O-methylvaginol (3), together with seven 
known compounds (4-10) were isolated from the fruits of Cnidium monnieri. Their structures were determined by detailed analysis of spectroscopic data and comparison with the data of known analogues. All the isolates were evaluated the cytoprotective activity by MTS cell proliferation assay and the results showed that all the three new 8-alkylcoumarins exhibited cytoprotective effect on Neuro-2a neuroblastoma cells injured by hydrogen peroxide.

Keywords: Chinese herb; Cnidium monnieri; 8-alkylcoumarin; oxidative stress

\section{Introduction}

Cnidium monnieri (L.) Cusson, belonging to the Umbelliferae family, is native to China and is an important traditional Chinese medicinal plant. It is widely distributed in China and is also found in Korea, Mongolia, and Russia. The dried fruits of C. monnieri, known in Chinese as "Shechuangzi", have been used as traditional remedies for the skin disease, gynecopathy, and stasis of the blood [1]. Several investigations have reported that the fruits of $C$. monnieri exhibited various pharmacological effects including antidermatophytic effect [2], antipruritic action [3], anti-allergic effect [4], antiosteoporosis [5], antiproliferation of vascular smooth muscle cells [6], vasorelaxation [7], antifibrotic activity in hepatic cells [8], and anti-adipogenic activity in 3T3-L1 cells [9]. In addition, the chemical constituents including coumarins [10], chromones [11], and sesquiterpens [12], have been isolated from the fruits of $C$. monnieri. The above-mentioned beneficial effects are suggested to be due to coumarin compounds existing in the dried fruits of $C$. monnieri [6] and more than twenty compounds, such as osthole, edultin bergapten, isopimpineline, cnidiadin, archangelicin, imperatorin, xanthotoxin, oroselone, colnmbianadin, $O$-acetylcolnmbianetin and $2^{\prime}$-acetylangelicin were found. The 8-alkylcoumarin compound, osthole, has been proven to regulate cardiac or hepatic oxidative stress by Zhou and Zhang [13,14]. The oxidative stress is considered to be one of the most important factors for neurodegenerative disease like Alzheimer's disease [15], thus in this study we aimed to explore the potential antioxidant candidates from the fruits of $C$. monnieri. Herein, we report the extraction, purification, structural elucidation, and cytoprotective activity of three new 8-alkylcoumarins (1-3) (Figure 1).

\section{Results and Discussion}

\subsection{Isolation and Structural Elucidation}

The $\mathrm{MeOH}$ extract of fruits of $C$. monnieri was concentrated to give a brown residue which was suspended in water and parititioned with EtOAc and $n-\mathrm{BuOH}$, successively. The combined EtOAc soluble layer was subjected to repeated chromatography using silica gel and further purification by semipreparative HPLC (high-performance liquid chromatography) to furnish three new compounds, 7-O-methylphellodenol-B (1), 7-methoxy-8-(3-methyl-2,3-epoxy-1-oxobutyl)chromen-2-one (2), and 3'-O-methylvaginol (3) (Figure 1), in addition to seven known compounds, 7-methoxy-8-formylcoumarin (4) [16], hassanon (5) [17], E-murraol (6) [18], Z-murraol (7) [19], micromarin-F (8) [20], meranziz hydrate (9) [21], and albiflorin-3 (10) [22]. The identification of the known compounds were 
performed by comparing their physical and spectral data (IR (infrared), UV (ultraviolet), MS (mass spectrum), and NMR (nuclear magnetic resonance)) with literature values.

Figure 1. The chemical structures of new compounds 1-3 isolated from Cnidium monnieri.

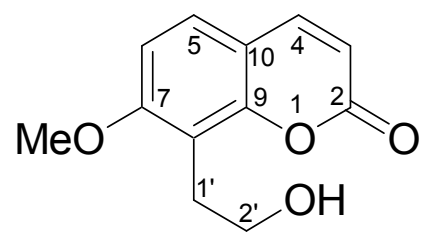

1

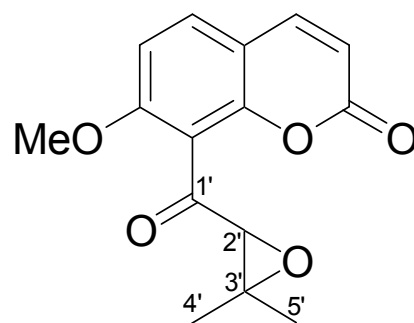

2

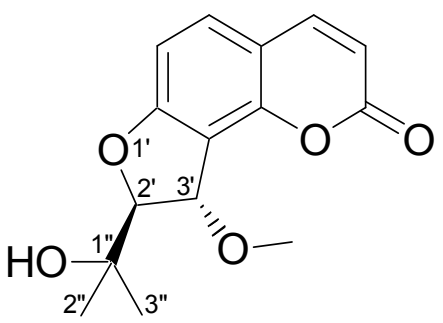

3

Compound 1 was obtained as a light yellow solid, and the high resolution electron impact mass spectrometry (HR-EI-MS) data determined the molecular formula to be $\mathrm{C}_{12} \mathrm{H}_{12} \mathrm{O}_{4}(\mathrm{~m} / z 220.0732 \text { ([M] }]^{+}$, calcd 220.0736)), indicating seven degrees of unsaturation. The IR spectrum indicated the presence of hydroxyl $\left(3250 \mathrm{~cm}^{-1}\right)$, carbonyl $\left(1719 \mathrm{~cm}^{-1}\right)$, and aromatic $\left(3065,1606\right.$ and $\left.1500 \mathrm{~cm}^{-1}\right)$ functionalities

The ${ }^{1} \mathrm{H}$ - and ${ }^{13} \mathrm{C}-\mathrm{NMR}$ spectra of $\mathbf{1}$ (Table 1) displayed signals characteristic of the presence of a methoxy $\left[\delta_{\mathrm{H}} 3.91(3 \mathrm{H}, \mathrm{s}) ; \delta_{\mathrm{C}} 56.1(\mathrm{q})\right]$, a $(Z)$-configured conjugated double bond of a six-membered ring $\left[\delta_{\mathrm{H}} 6.23(1 \mathrm{H}, \mathrm{d}, J=9.5 \mathrm{~Hz}, \mathrm{H}-3), 7.61(1 \mathrm{H}, \mathrm{d}, J=9.5 \mathrm{~Hz}, \mathrm{H}-4) ; \delta_{\mathrm{C}} 113.1\right.$ (d), 143.8 (d)], two ortho-coupled aromatic protons $\left[\delta_{\mathrm{H}} 7.32(1 \mathrm{H}, \mathrm{d}, J=8.6 \mathrm{~Hz}, \mathrm{H}-5), 6.84(1 \mathrm{H}, \mathrm{d}, J=8.6 \mathrm{~Hz}, \mathrm{H}-6)\right.$; $\left.\delta_{\mathrm{C}} 127.0(\mathrm{~d}), 107.3(\mathrm{~d})\right]$, and a hydroxyethyl group attached on the benzene ring $\left[\delta_{\mathrm{H}} 3.15(2 \mathrm{H}, \mathrm{t}, J=6.7 \mathrm{~Hz}\right.$, $\left.\left.\mathrm{H}-1^{\prime}\right), 3.84\left(1 \mathrm{H}, \mathrm{d}, J=6.7 \mathrm{~Hz}, \mathrm{H}-2^{\prime}\right) ; \delta_{\mathrm{C}} 26.3(\mathrm{t}), 62.0(\mathrm{t})\right]$. Twelve carbon signals were found in the ${ }^{13} \mathrm{C}$-NMR spectrum of $\mathbf{1}$ and were assigned by the distortionless enhancement by polarization transfer (DEPT) experiments as one aliphatic methylene, four olefinic methine, four quaternary olefinic, one secondary oxygenated, one carbonyl, and one methoxy carbons. On the basis of above spectral evidences, compound 1 was tentatively proposed to be a coumarin derivative exhibiting a methoxyl group neighbouring a hydroxyethyl group bonded to the benzene ring. The heteronuclear multiple bond coherence (HMBC) correlations (Figure 2) between H-4 $\left(\delta_{\mathrm{H}} 7.61\right) / \mathrm{C}-2\left(\delta_{\mathrm{C}} 161.3(\mathrm{~s})\right)$, C-5 $\left(\delta_{\mathrm{C}} 127.0(\mathrm{~d})\right)$, and C-9 $\left(\delta_{\mathrm{C}} 153.4(\mathrm{~d})\right)$; H-5 $\left(\delta_{\mathrm{H}} 7.32\right) / \mathrm{C}-7\left(\delta_{\mathrm{C}} 160.7(\mathrm{t})\right)$ and C-9; and H-6 $\left(\delta_{\mathrm{H}} 6.84\right) / \mathrm{C}-8$ $\left(\delta_{\mathrm{C}} 114.9(\mathrm{~s})\right)$ confirmed the coumarin skeletal structure of $\mathbf{1}$. The HMBC correlations between 7-OMe $\left(\delta_{\mathrm{H}} 3.91\right) / \mathrm{C}-7 ; \mathrm{H}-1^{\prime}\left(\delta_{\mathrm{H}} 3.15\right) / \mathrm{C}-7, \mathrm{C}-8$, and C-9 indicated that the methoxyl group and hydroxyethyl group were attached on $\mathrm{C}-7$ and $\mathrm{C}-8$, respectively. The significant nuclear Overhauser enhancement spectroscopy (NOESY) correlations between H-4/H-5 and H-6/7-OMe further confirmed the above proposal structure (Figure 2). Therefore compound 1 was determined as 7-O-methylphellodenol-B. Complete ${ }^{1} \mathrm{H}$ - and ${ }^{13} \mathrm{C}-\mathrm{NMR}$ chemical shifts were established by ${ }^{1} \mathrm{H}-{ }^{1} \mathrm{H}$ correlated spectroscopy $\left({ }^{1} \mathrm{H}-{ }^{1} \mathrm{H} \mathrm{COSY}\right)$, heteronuclear multiple-quantum coherence (HMQC), HMBC, and NOESY spectra.

Compound 2 was obtained as a yellow oil, and the high resolution electron impact mass spectrometry (HR-EI-MS) data determined the molecular formula to be $\mathrm{C}_{15} \mathrm{H}_{14} \mathrm{O}_{5}(\mathrm{~m} / z 274.0834$ $\left([\mathrm{M}]^{+}\right.$, calcd 274.0841)), indicating nine degrees of unsaturation. The IR spectrum indicated the presence of two carbonyl (1732 and $\left.1716 \mathrm{~cm}^{-1}\right)$, and aromatic (3061, 1600 and $1507 \mathrm{~cm}^{-1}$ ) functionalities. The ${ }^{1} \mathrm{H}$ - and ${ }^{13} \mathrm{C}-\mathrm{NMR}$ spectra of 2 (Table 1) revealed resonances for a methoxy 
$\left[\delta_{\mathrm{H}} 3.92(3 \mathrm{H}, \mathrm{s}) ; \delta_{\mathrm{C}} 56.6(\mathrm{q})\right]$, a $(Z)$-configured conjugated double bond of a six-membered ring [ $\left.\delta_{\mathrm{H}} 6.27(1 \mathrm{H}, \mathrm{d}, J=9.6 \mathrm{~Hz}), 7.62(1 \mathrm{H}, \mathrm{d}, J=9.6 \mathrm{~Hz}) ; \delta_{\mathrm{C}} 113.4(\mathrm{~d}), 142.8(\mathrm{~d})\right]$, two ortho-coupled aromatic protons $\left[\delta_{\mathrm{H}} 7.51(1 \mathrm{H}, \mathrm{d}, J=8.8 \mathrm{~Hz}), 6.89(1 \mathrm{H}, \mathrm{d}, J=8.8 \mathrm{~Hz}) ; \delta_{\mathrm{C}} 130.9\right.$ (d), 104.3 (d)], a conjugated ketone carbonyl [ $\left.\delta_{\mathrm{C}} 195.2(\mathrm{~s})\right]$, an oxymethine $\left[\delta_{\mathrm{H}} 3.83(1 \mathrm{H}, \mathrm{s}) ; \delta_{\mathrm{C}} 66.8(\mathrm{~d})\right]$, and a quaternary oxygenated carbon $\left[\delta_{\mathrm{C}} 63.7(\mathrm{~s})\right]$ linked with two methyls $\left[\delta_{\mathrm{H}} 1.45,1.52\right.$ (each $3 \mathrm{H}, \mathrm{s}$ ); $\delta_{\mathrm{C}} 18.5$ (q), $\left.24.8(\mathrm{q})\right]$. Altogether, 15 carbon signals were observed in the ${ }^{13} \mathrm{C}-\mathrm{NMR}$ spectrum of 2 and were assigned by DEPT (distortionless enhancement by polarization transfer) experiments as two alphatic methyl, four olefinic methine, four quaternary olefinic, one tertiary oxygenated, one quaternary oxygenated, two carbonyl, and one methoxy carbons. By comparison of the ${ }^{1} \mathrm{H}-$ and ${ }^{13} \mathrm{C}-\mathrm{NMR}$ data with those of $\mathbf{1}$, indicated that both compounds exhibited identical structure in coumarin skeleton, the obvious differences occur in the signals of side chain at C-8. The NMR signals of hydroxyethyl group at C-8 were absent in $\mathbf{1}$, replaced by that of a side chain composed of five carbons including a conjugated ketone carbonyl $\left[\delta_{\mathrm{C}} 195.2(\mathrm{~s})\right]$, an oxymethine $\left[\delta_{\mathrm{H}} 3.83(1 \mathrm{H}, \mathrm{s}) ; \delta_{\mathrm{C}} 66.8(\mathrm{~d})\right]$, and a quaternary oxygenated carbon $\left[\delta_{\mathrm{C}} 63.7(\mathrm{~s})\right]$ linked with two methyls $\left[\delta_{\mathrm{H}} 1.45,1.52\right.$ (each $3 \mathrm{H}, \mathrm{s}$ ); $\left.\delta_{\mathrm{C}} 18.5(\mathrm{q}), 24.8(\mathrm{q})\right]$. The structure of side chain was determined as 3-methyl-2,3-epoxy-1-oxobutyryl moiety by HMBC correlations as follows: H-2' $\left(\delta_{\mathrm{H}} 3.83\right) / \mathrm{C}-1^{\prime}\left(\delta_{\mathrm{C}} 195.2\right), \mathrm{C}-3^{\prime}\left(\delta_{\mathrm{C}} 63.7\right), \mathrm{C}-4^{\prime}\left(\delta_{\mathrm{C}} 18.5\right)$, and $\mathrm{C}-5^{\prime}\left(\delta_{\mathrm{C}} 24.8\right)$ and $\mathrm{H}-4^{\prime}\left(\delta_{\mathrm{H}} 1.45\right) / \mathrm{C}-2^{\prime}\left(\delta_{\mathrm{C}} 66.8\right)$ and $\mathrm{C}-3^{\prime}$ (Figure 2). Thus, compound 2 was accordingly determined to be 7-methoxy-8-(3-methyl-2,3-epoxy-3-oxobutyl)chromen-2-one.

Compound $\mathbf{3}$ was obtained as a light yellow solid. The IR spectrum of $\mathbf{3}$ showed bands that were attributable to hydroxyl $\left(3462 \mathrm{~cm}^{-1}\right)$, carbonyl $\left(1725 \mathrm{~cm}^{-1}\right)$, and aromatic $\left(3055,1615,1460 \mathrm{~cm}^{-1}\right)$ functionalities. The ${ }^{1} \mathrm{H}$ - and ${ }^{13} \mathrm{C}-\mathrm{NMR}$ spectra of 3 (Table 1) revealed resonances for a methoxy $\left[\delta_{\mathrm{H}} 3.63(3 \mathrm{H}, \mathrm{s}) ; \delta_{\mathrm{C}} 57.9(\mathrm{q})\right]$, a $(Z)$-configured conjugated double bond of a six-membered ring [ $\left.\delta_{\mathrm{H}} 6.23(1 \mathrm{H}, \mathrm{d}, J=9.4 \mathrm{~Hz}), 7.62(1 \mathrm{H}, \mathrm{d}, J=9.4 \mathrm{~Hz}) ; \delta_{\mathrm{C}} 112.4(\mathrm{~d}), 143.4(\mathrm{~d})\right]$, two ortho-coupled protons $\left[\delta_{\mathrm{H}} 7.37(1 \mathrm{H}, \mathrm{d}, J=8.4 \mathrm{~Hz}), 6.80(1 \mathrm{H}, \mathrm{d}, J=8.4 \mathrm{~Hz}) ; \delta_{\mathrm{C}} 131.8(\mathrm{~d}), 107.3(\mathrm{~d})\right.$ ], and two oxymethines $\left[\delta_{\mathrm{H}} 4.51(1 \mathrm{H}, \mathrm{d}, J=2.8 \mathrm{~Hz}), 5.21(1 \mathrm{H}, \mathrm{d}, J=2.8 \mathrm{~Hz}) ; \delta_{\mathrm{C}} 96.1(\mathrm{~d}), 79.4(\mathrm{~d})\right]$, and a quaternary oxygenated carbon $\left[\delta_{\mathrm{C}} 71.4(\mathrm{~s})\right]$ linked to two methyls $\left[\delta_{\mathrm{H}} 1.25,1.31\right.$ (each $3 \mathrm{H}, \mathrm{s}$ ); $\delta_{\mathrm{C}} 25.2$ (q), 25.7 (q)]. The ${ }^{13} \mathrm{C}$-NMR spectrum displayed 15 resonances, which were differentiated by DEPT experiments into two aliphatic methyl, four olefinic methine, four quaternary olefinic, two tertiary oxygenated, one quaternary oxygenated, one carbonyl, and one methoxy carbons. These data suggested that $\mathbf{3}$ was a coumarin similar to compound 2. The HR-EI-MS of $\mathbf{3}$ showed a molecular ion at $m / z$ 276.0999, which corresponded to the molecular formula, $\mathrm{C}_{15} \mathrm{H}_{16} \mathrm{O}_{5}$, indicating eight degrees of unsaturation. Seven of eight degrees of unsaturation attributed to the basic structure of coumarin and the remaining one degree of unsaturation suggested two substituents of C-7 and C-8 should exhibit a ring structure. The two vicinal oxymethines $\left[\delta_{\mathrm{H}} 4.51(1 \mathrm{H}, \mathrm{d}, J=2.8 \mathrm{~Hz}), 5.21(1 \mathrm{H}, \mathrm{d}, J=2.8 \mathrm{~Hz})\right.$; $\left.\delta_{\mathrm{C}} 96.1(\mathrm{~d}), 79.4(\mathrm{~d})\right]$, a downshifted methoxy $\left[\delta_{\mathrm{H}} 3.63(3 \mathrm{H}, \mathrm{s}) ; \delta_{\mathrm{C}} 57.9(\mathrm{q})\right]$ attached on a aliphatic carbon, and two methyls $\left[\delta_{\mathrm{H}} 1.45,1.52\right.$ (each $3 \mathrm{H}, \mathrm{s}$ ); $\delta_{\mathrm{C}} 18.5,24.8$ (q)] linked to an oxygenated quaternary carbon $\left[\delta_{\mathrm{C}} 63.7(\mathrm{~s})\right]$ indicated that 3 exhibited a dihydrofuran structure bonded to C-7 and C-8 with two substituents, a methoxy and a 2-hydroxyisopropyl moiety. The proposal structure was confirmed by HMBC correlations as follows: H-2' $\left(\delta_{\mathrm{H}} 4.51\right) / \mathrm{C}-7$ and C-3' $\left(\delta_{\mathrm{C}} 79.4\right) ; \mathrm{H}-3^{\prime}\left(\delta_{\mathrm{H}} 5.21\right) / \mathrm{C}-7$ $\left(\delta_{\mathrm{C}} 163.9\right), \mathrm{C}-8\left(\delta_{\mathrm{C}} 112.9\right)$, and C-1" $\left(\delta_{\mathrm{C}} 71.4\right)$; H-2" $\left(\delta_{\mathrm{H}} 1.25\right) / \mathrm{C}-2^{\prime}$ and C-1"; 3'-OMe $\left(\delta_{\mathrm{H}} 3.63\right) / \mathrm{C}-3^{\prime}$ (Figure 2). The trans-configuration at C-2' and C-3' was determined by significant NOE (nuclear Overhauser enhancement) correlations between $\mathrm{H}-2^{\prime} / 3^{\prime}-\mathrm{OMe}$ and $\mathrm{H}-3^{\prime} / \mathrm{H}-3^{\prime \prime}$ in the NOESY spectrum. 
No NOESY correlation was found between $\mathrm{H}-2^{\prime}$ and $\mathrm{H}-3^{\prime}$ that further confirmed this assignment (Figure 2). Accordingly, compound 3 was determined to be 3'-O-methylvaginol.

Table 1. NMR (nuclear magnetic resonance) data $\left(\mathrm{CDCl}_{3}\right)$ of compounds $\mathbf{1}-\mathbf{3}$. $\delta$ in ppm, $J$ in $\mathrm{Hz}$.

\begin{tabular}{|c|c|c|c|c|c|c|}
\hline \multirow[t]{2}{*}{ Position } & \multicolumn{2}{|c|}{ Compound 1} & \multicolumn{2}{|c|}{ Compound 2} & \multicolumn{2}{|c|}{ Compound 3} \\
\hline & $\delta_{H}{ }^{a}$ & $\boldsymbol{\delta}_{\mathrm{C}}^{\mathbf{b}}$ & $\delta_{H}{ }^{c}$ & $\delta_{C}{ }^{d}$ & $\delta_{H}{ }^{c}$ & $\delta_{C}^{d}$ \\
\hline \multicolumn{7}{|l|}{1} \\
\hline 2 & & 161.3 & & 159.8 & & 159.9 \\
\hline 3 & $6.23(\mathrm{~d}, J=9.5)$ & 113.1 & $6.27(\mathrm{~d}, J=9.6)$ & 113.4 & $6.23(\mathrm{~d}, J=9.4)$ & 112.4 \\
\hline 4 & $7.61(\mathrm{~d}, J=9.5)$ & 143.8 & $7.62(\mathrm{~d}, J=9.6)$ & 142.8 & $7.62(\mathrm{~d}, J=9.4)$ & 143.4 \\
\hline 5 & $7.32(\mathrm{~d}, J=8.6)$ & 127.0 & $7.51(\mathrm{~d}, J=8.8)$ & 130.9 & $7.37(\mathrm{~d}, J=8.4)$ & 131.8 \\
\hline 6 & $6.84(\mathrm{~d}, J=8.6)$ & 107.3 & $6.89(\mathrm{~d}, J=8.8)$ & 104.3 & $6.80(\mathrm{~d}, J=8.4)$ & 107.3 \\
\hline 7 & & 160.7 & & 159.2 & & 163.9 \\
\hline 8 & & 114.9 & & 116.2 & & 112.9 \\
\hline 9 & & 153.4 & & 152.4 & & 151.7 \\
\hline 10 & & 113.0 & & 112.7 & & 113.9 \\
\hline $1^{\prime}$ & $3.15(\mathrm{t}, J=6.7)$ & 26.3 & & 195.2 & & \\
\hline $2^{\prime}$ & $3.84(\mathrm{t}, J=6.7)$ & 62.0 & $3.83(\mathrm{~s})$ & 66.8 & $4.51(\mathrm{~d}, J=2.8)$ & 96.1 \\
\hline $3^{\prime}$ & & & & 63.7 & $5.21(\mathrm{~d}, J=2.8)$ & 79.4 \\
\hline $4^{\prime}$ & & & $1.45(\mathrm{~s})$ & 18.5 & & \\
\hline $5^{\prime}$ & & & $1.52(\mathrm{~s})$ & 24.8 & & \\
\hline $1 "$ & & & & & & 71.4 \\
\hline $2^{\prime \prime}$ & & & & & $1.25(\mathrm{~s})$ & 25.2 \\
\hline $3 "$ & & & & & $1.31(\mathrm{~s})$ & 25.7 \\
\hline $\mathrm{OCH}_{3}$ & $3.91(\mathrm{~s})$ & 56.1 & $3.92(\mathrm{~s})$ & 56.6 & $3.63(\mathrm{~s})$ & 57.9 \\
\hline
\end{tabular}

\subsection{Cytoprotective Activity against Oxidative Stress}

The oxidative stress is considered to be one of the most important factors for neurodegenerative disease like Alzheimer's disease [15]. $\mathrm{H}_{2} \mathrm{O}_{2}$-treatment has been shown to cause oxidative stress to the cells in culture [23] and impaired their proliferation. The cytoprotective activity against oxidative stress induced by hydrogen peroxide on Neuro-2a cells was assayed. All the isolates were evaluated the anti-oxidative activity by MTS (3-(4,5-dimethylthiazol-2-yl)-5-(3-carboxymethoxyphenyl)-2(4-sulfophenyl)-2H-tetrazolium) cell proliferation assay and the results showed that all these three new 8-alkylcoumarins exhibited cytoprotective effect on Neuro-2a cells injured by hydrogen peroxide. The range of effective cytoprotective dosage for compound 1 was from 0.25 to $1 \mu \mathrm{M}$. Interestingly, compound $\mathbf{3}$ dramatically increased the cytoprotective effect at a lower dosage, $0.1 \mu \mathrm{M}$. Compound 2 showed slight cytoprotective ability at the concentration ranging from 0.1 to $1 \mu \mathrm{M}$ (Figure 3 ). The remaining seven known compounds (4-10) exhibited no significant cytoprotective activity. 
Figure 2. Significant heteronuclear multiple bond coherence (HMBC) and nuclear Overhauser enhancement spectroscopy (NOESY) correlations (two-headed arrows) of compounds 1-3.

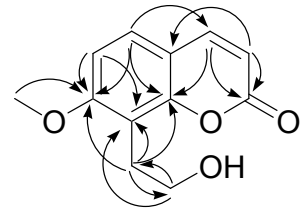

HMBC of 1

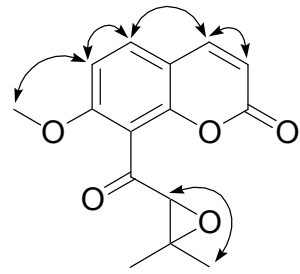

NOESY of 2

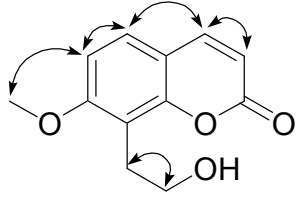

NOESY of 1

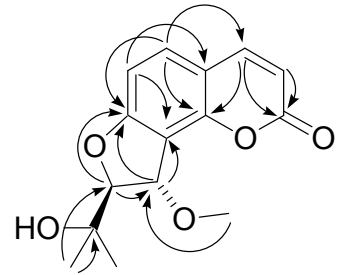

HMBC of 3

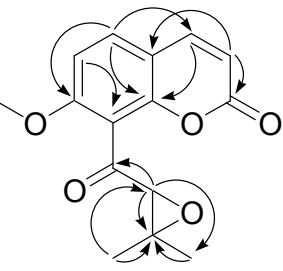

HMBC of 2

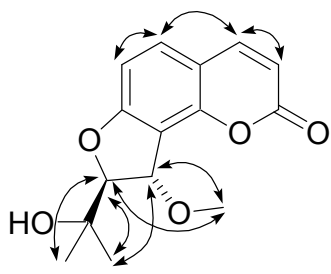

NOESY of 3

Figure 3. Protective effect from $\mathrm{H}_{2} \mathrm{O}_{2}$-induced oxidative stress on Neuro-2a neuroblastoma cells of (A) compound 1; (B) compound 2; and (C) compound 3 . The cell viability is expressed as a percentage relative to control without $\mathrm{H}_{2} \mathrm{O}_{2}$ treatment. Values are mean \pm SEM from three experiments. The asterisk symbol $\left({ }^{*}\right)$ indicates a statistically significant difference $(p<0.05)$ in relation to control with $\mathrm{H}_{2} \mathrm{O}_{2}$ treatment. The symbol (\#) indicates a statistically significant difference $(p<0.05)$ between each experimental group. N.S. means not significant.
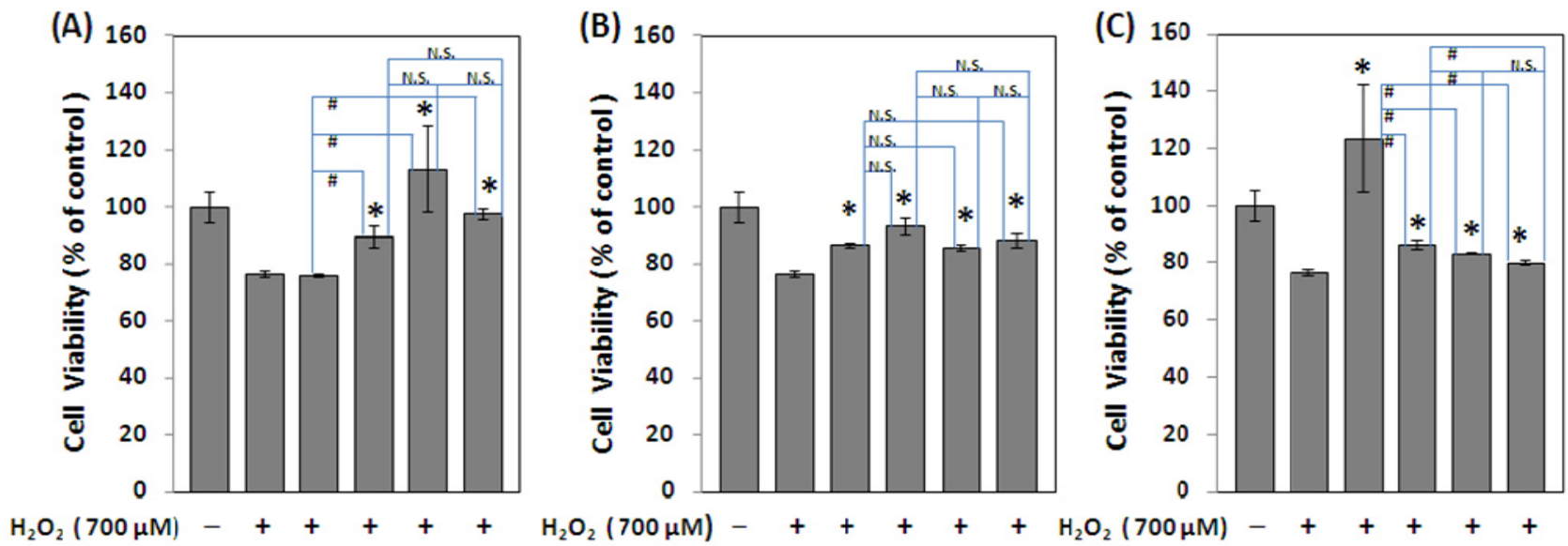

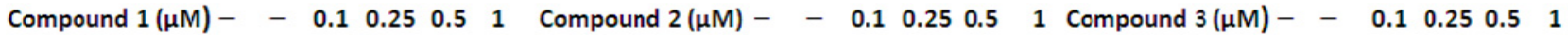




\section{Experimental Section}

\subsection{Chemicals}

Thirty percent hydrogen peroxide stock solution, 3-(4,5-dimethylthiazol-2-yl)-5-(3-carboxy methoxyphenyl)-2-(4-sulfophenyl)-2H-tetrazolium (MTS) and other chemicals were purchased from Sigma-Aldrich Chemical Co. (St. Louis, MO, USA).

\subsection{General}

UV spectra were obtained using a Shimadzu Pharmaspec-1700 UV-Visible spectrophotometer. Optical rotations were measured with a Jasco-DIP-180 polarimeter (JASCO, Inc., Tokyo, Japan). Infrared spectra were recorded on a Perkin-Elmer-983G FT-IR spectrophotometer (PerkinElmer Ltd., Bucks, UK). 1D- and 2D-NMR spectra were measured with a Varian-Unity-Plus-400 spectrometer or a Bruker DRX-500 FT-NMR spectrometer with tetramethylsilane (TMS) as the internal standard (Bruker Instruments, Karlsruhe, Germany). EI-MS and HR-EI-MS were measured with a JEOL SX-102A mass spectrometer and a Finnigan TSQ-46C mass spectrometer, respectively (Finnigan MAT, Inc., San Jose, CA, USA). Column chromatography was performed using Merck Si gel (230-400 mesh; Merck \& Co., Inc., White House Station, NJ, USA), and TLC (thin-layer chromatography) analysis was carried out using aluminum pre-coated Si plates (Silica Gel 60 F-254; Merck \& Co., Inc.); the spots were detected by spraying with $5 \% \mathrm{H}_{2} \mathrm{SO}_{4}$ and then heating at $100{ }^{\circ} \mathrm{C}$. Semi-preparative HPLC was performed using a normal phase column (LiChrosorb Si 60, $7 \mu \mathrm{m}$, $250 \mathrm{~mm} \times 10 \mathrm{~mm}$; Merck \& Co., Inc.) on a LDC Analytical-III system.

\subsection{Plant Material}

The fruits of $C$. monnieri were purchased from a local medicine store in Taipei, Taiwan. The material was identified by Prof. Chao-Lin Kuo, Department of Chinese Pharmaceutical Science and Chinese Medicine Resources, China Medical University.

\subsection{Extraction and Isolation}

Dried fruits $(6.45 \mathrm{~kg})$ of C. monnieri (L.) were extracted with $\mathrm{MeOH}(40 \mathrm{~L})$ two times (7 days each time) at room temperature. After removal of the solvent under vacuum, the extract was suspended in water $(1 \mathrm{~L})$, and then partitioned with EtOAc $(1 \mathrm{~L} \times 3)$ to yield a brown residue $(338 \mathrm{~g})$. The EtOAc fraction was chromatographed on silica gel $(4.2 \mathrm{~kg}, 120 \mathrm{~mm} \times 10 \mathrm{~cm})$ using $n$-hexane-EtOAc and EtOAc-MeOH mixtures as solvent systems to obtain 11 fractions. Fraction 6 from $n$-hexane-EtOAc (6:4) elution was further chromatographed on a silica gel column $(5 \mathrm{~mm} \times 45 \mathrm{~cm})$, eluted with $\mathrm{CH}_{2} \mathrm{Cl}_{2}$-EtOAc (8:1 to $0: 1$ ) to give seven fractions (each about $500 \mathrm{~mL}$ ), 6A-6G. Fraction 6A was subjected to semipreparative HPLC eluted with $n$-hexane-EtOAc (7:3) and $n$-hexane- $\mathrm{CH}_{2} \mathrm{Cl}_{2}-\mathrm{EtOAc}$ (3:3:4) and to yield 4 (27.9 mg, 0.00433\%o). Fraction 6C was subjected to semipreparative HPLC eluted with $\mathrm{CH}_{2} \mathrm{Cl}_{2}$-EtOAc (4:1) and $n$-hexane- $\mathrm{CH}_{2} \mathrm{Cl}_{2}-\mathrm{MeOH}$ (11:8:1) and to yield 6 (4.8 mg, $0.00074 \%$ ), 7 (28.5 mg, 0.00442\%o), and 8 (43.1 mg, 0.00668\%o). Fraction 6D was subjected to semipreparative HPLC eluted with $n$-hexane- $\mathrm{CH}_{2} \mathrm{Cl}_{2}-$ EtOAc (3:8:9) and $n$-hexane- $\mathrm{CH}_{2} \mathrm{Cl}_{2}-\mathrm{MeOH}$ 
(7:10:1) to yield $3(1.2 \mathrm{mg}, 0.00019 \%), 9(2.2 \mathrm{mg}, 0.00034 \%$ ), and $\mathbf{1 0}(5.0 \mathrm{mg}, 0.00077 \%$ ). Fraction 6E was subjected to semipreparative HPLC eluted with $n$-hexane-EtOAc $(9: 11)$ and $n$-hexane- $\mathrm{CH}_{2} \mathrm{Cl}_{2}-\mathrm{MeOH}$ (8:11:1) to yield 1 (27.9 $\mathrm{mg}, 0.00433 \%$ ), 2 (1.0 mg, 0.00016\%o), and 5 (2.1 mg, 0.00033\%o).

7-O-Methylphellodenol-B (1). Light yellow solid; mp: $213-215{ }^{\circ} \mathrm{C}$; EI-MS (70 eV) $\mathrm{m} / z$ (rel. int.\%): 220 ([M] $\left.]^{+}, 33\right), 190$ (99), 189 (100), 175 (15), 161 (13), 131 (85); HR-EI-MS m/z: 220.0732 [M] (calcd for $\mathrm{C}_{12} \mathrm{H}_{12} \mathrm{O}_{4}, 220.0736$ ); UV $\lambda_{\max }(\mathrm{MeOH}): 320,255,247,218 \mathrm{~nm}$; IR (KBr) $v \max$ : 3250, 3065, $1719,1606,1500,1275,1255,1102,1009,844 \mathrm{~cm}^{-1} ;{ }^{1} \mathrm{H}-\mathrm{NMR}$ and ${ }^{13} \mathrm{C}-\mathrm{NMR}(500 / 125 \mathrm{MHz}$, in $\left.\mathrm{CDCl}_{3}\right)$ : see Table 1.

7-Methoxy-8-(3-methyl-2,3-epoxy-1-oxobutyryl)chromen-2-one (2). Yellow oil; $[\alpha]^{25}{ }_{\mathrm{D}}=-171.0^{\circ}$ $(c=0.03, \mathrm{MeOH})$; EI-MS (70 eV) $m / z$ (rel. int.\%): 274 ([M] $\left.]^{+}, 24\right), 259$ (23), 203 (100); HR-EI-MS $m / z: 274.0834[\mathrm{M}]^{+}$(calcd for $\left.\mathrm{C}_{15} \mathrm{H}_{14} \mathrm{O}_{5}, 274.0841\right)$; UV $\lambda_{\max }(\mathrm{MeOH}): 322,303,231,211 \mathrm{~nm}$; IR (KBr) vmax: 3061, 1732, 1716, 1600, 1507, 1295, 1255, 1096, $837 \mathrm{~cm}^{-1} ;{ }^{1} \mathrm{H}-\mathrm{NMR}$ and ${ }^{13} \mathrm{C}-\mathrm{NMR}$ (400/100 MHz, in $\left.\mathrm{CDCl}_{3}\right)$ : see Table 1.

3'-O-Methylvaginol (3). Light yellow solid; mp: $155-157^{\circ} \mathrm{C} ;[\alpha]_{\mathrm{D}}^{25} \approx 0^{\circ}(c=0.04, \mathrm{MeOH})$; EI-MS (70 eV) $m / z$ (rel. int.\%): 276 ([M] $\left.]^{+}, 37\right), 243$ (68), 187 (100), 158 (19); HR-EI-MS m/z: 276.0999 [M] $]^{+}$ (calcd for $\left.\mathrm{C}_{15} \mathrm{H}_{16} \mathrm{O}_{5}, 276.0997\right)$; UV $\lambda_{\max }(\mathrm{MeOH}): 324,259,249,217 \mathrm{~nm}$; IR (KBr) $v_{\max }$ 3462, 3055, 1725, 1615, 1460, 1255, 1116, $837 \mathrm{~cm}^{-1}$; ${ }^{1} \mathrm{H}-\mathrm{NMR}$ and ${ }^{13} \mathrm{C}-\mathrm{NMR}\left(400 / 100 \mathrm{MHz}\right.$, in $\left.\mathrm{CDCl}_{3}\right)$ : see Table 1.

\subsection{Cell Culture}

Neuro-2a neuroblastoma cells (BCRC 60026) was purchased from the Bioresources Collection and Research Center (BCRC, Hsinchu, Taiwan) of the Food Industry Research and Development Institute (Hsinchu, Taiwan). Cells were cultured in plastic dishes containing Dulbecco's Modified Eagle Medium (DMEM, Sigma, St. Louis, MO, USA) supplemented with 10\% fetal bovine serum (FBS, Sigma) in a $\mathrm{CO}_{2}$ incubator $\left(5 \% \mathrm{CO}_{2}\right.$ in air) at $37{ }^{\circ} \mathrm{C}$ and subcultured every 3 days at a dilution of $1: 3$ using $0.05 \%$ trypsin- $0.02 \%$ EDTA in $\mathrm{Ca}^{2+}$ - and $\mathrm{Mg}^{2+}$-free phosphate-buffered saline (DPBS).

\subsection{Cell Viability Assay}

The 3-(4,5-dimethylthiazol-2-yl)-5-(3-carboxymethoxyphenyl)-2-(4-sulfophenyl)-2H-tetrazolium (MTS) assay was performed to determine the anti-oxidative effects of three new 8-alkylcoumarins on Neuro-2a cell viability according to the manufacturer's protocol. Cells $\left(10^{4}\right)$ were cultured in 96 -well plate containing DMEM (Dulbecco's modified eagle's medium) supplemented with 10\% FBS for 1 day to become nearly confluent. Then, cells were cultured with different concentrations of the three new compounds (1-3) and seven known compounds (4-10). After $1 \mathrm{~h}$, cells were cultured in the presence of $700 \mu \mathrm{M}$ hydrogen peroxide (Sigma-Aldrich) for further $7 \mathrm{~h}$. After that, the cells were washed with DPBS and $120 \mu \mathrm{L}$ MTS solution. After $2 \mathrm{~h}$ incubation at $37^{\circ} \mathrm{C}$, the absorbance at $490 \mathrm{~nm}$ was read using a microplate reader (Molecular Devices, Sunnyvale, CA, USA). All tests were performed in triplicate. Results are expressed as the percentage relative to control without $\mathrm{H}_{2} \mathrm{O}_{2}$ treatment. 


\subsection{Statistical Analysis}

Multiple comparisons within experimental groups were made using one-way analysis of variance (ANOVA) to determine differences between experimental treatments and control with $\mathrm{H}_{2} \mathrm{O}_{2}$ treatment. A level of $p<0.05$ was set for significance for all tests, and all values are expressed as mean $\pm \mathrm{SEM}$.

\section{Conclusions}

Ten coumarins were isolated from the fruits of $C$. monnieri. Among them, 7-O-methylphellodenol-B (1), 7-methoxy-8-(3-methyl-2,3-epoxy-1-oxobutyl)chromen-2-one (2), and 3'-O-methylvaginol (3) are new compounds. This investigation of secondary metabolites may contribute to better understanding on the chemical characteristics of C. monnieri.

The three new compounds 1-3 exhibited significant cytoprotective activity (Figure 3 ). Compounds $\mathbf{1}$ and 3 showed stronger cytoprotective activity than compound $\mathbf{2}$. The dose range of cytoprotective effect for compound 1 was from 0.25 to $1 \mu \mathrm{M}$, and no significant difference was observed between the different concentrations, $0.25,0.5$, and $1 \mu \mathrm{M}$ through the ANOVA analysis. Compound 3 showed better cytoprotective effect at the low dosage $(0.1 \mu \mathrm{M})$, which may be due to its good scavenging ability against hydrogen peroxide. However, at the higher dosage, the cytoprotective effect of compound $\mathbf{3}$ was dramatically decreased, which may be due to its intrinsic cytotoxicity. Compound $\mathbf{2}$ showed a weaker cytoprotective effect compared to that of compounds $\mathbf{1}$ and $\mathbf{3}$ (Figure 3). It may be explained by the intrinsic cytotoxicity of compound $\mathbf{2}$ contributed by its reactive epoxide group [24,25]. In conclusion, we found that these three new 8-alkylcoumarins from the fruits of $C$. monnieri, 7-O-methylphellodenol-B (1), 7-methoxy-8-(3-methyl-2,3-epoxy-1-oxobutyl)chromen-2-one (2), and 3'-O-methylvaginol (3) could effectively protect Neuro-2a neuroblastoma cells from oxidative damage at the specific dose range.

\section{Acknowledgments}

Financial was supported from the China Medical University (CMU99-Tsuzuki) and the Taiwan Department of Health Clinical Trial, China Medical University Hospital (DMR-102-109), and Research Center of Excellence (DOH 102-TD-B-111-004). We thank Shu-Yun Sun for the MS measurements in the Instrumentation Center of the College of Science, National Taiwan University. We are also grateful to the National Center for high-performance computing for computer time and facilities.

\section{Author Contributions}

Yueh-Hsiung Kuo and Wei-Yong Lin designed research; Chi-I Chang, Wan-Chiao Hu, and Wei-Yong Lin performed research; Che-Piao Shen, Ban-Dar Hsu, Ping-Jyun Sung, Wei-Hsien Wang, and Jin-Bin Wu contributed new analytical tools and reagents; Yueh-Hsiung Kuo, Wei-Yong Lin, and Chi-I Chang wrote the paper.

\section{Conflicts of Interest}

The authors declare no conflict of interest. 


\section{References}

1. Ou, M. Chinese-English Manual of Commonly Used Traditional Chinese Medicine; Joint Publishing: Hong Kong, China, 1989; p. 522.

2. Honda, G.; Tabata, M.; Baba, K.; Kozawa, M. On the antidermatophytic constituents and the original plants of the traditional Chinese drug "Shechuangzi”. Shoyakugaku Zasshi 1984, 38, 221-226.

3. Basnet, P.; Yasuda, I.; Kumagai, N.; Tohda, C.; Nojima, H.; Kuraishi, Y.; Komatsu, K. Inhibition of itch-scratch response by fruits of Cnidium monnieri in mice. Biol. Pharm. Bull. 2001, 24, 1012-1015.

4. Matsuda, H.; Tomohiro, N.; Ido, Y.; Kubo, M. Anti-allergic effects of Cnidium monnieri Fructus (dried fruits of Cnidium monnieri) and its major component, osthol. Biol. Pharm. Bull. 2002, 25, 809-812.

5. Zhang, Q.Y.; Qin, L.P.; He, W.D.; Puyvelde, L.V.; Adams, D.M.; Zheng, H.C.; Kimpe, N.D. Coumarins from Cnidium monnieri and their antiosteoporotic activity. Planta Med. 2007, 73, 13-19.

6. Juh, G.H.; Yu, S.M.; Ko, F.N.; Wu, T.S.; Teng, C.M. Antiproliferative effect in rat vascular smooth muscle cells by osthole, isolated from Angelica pubescens. Eur. J. Pharmacol. 1996, 298, 191-197.

7. Chiou, W.F.; Huang, Y.L.; Chen, C.F.; Chen, C.C. Vasorelaxing effect of coumarins from Cnidium monnieri on rabbit corpus cavernosum. Planta Med. 2001, 67, 282-284.

8. Shin, E.; Lee, E.; Sung, S.H.; Kim, Y.C.; Hwang, B.Y.; Lee, M.K. Antifibrotic activity of coumarins from Cnidium monnieri fruits in HSC-T6 hepatic stellate cells. J. Nat. Med. 2011, 65, $370-374$.

9. Kim, S.B.; Ahn, J.H.; Han, S.B.; Hwang, B.Y.; Kim, S.Y.; Lee, M.K. Anti-adipogenic chromone glycosides from Cnidium monnieri fruits in 3T3-L1 cells. Bioorg. Med. Chem. Lett. 2012, 22, 6267-6271.

10. Cai, J.N.; Basnet, P.; Wang, Z.T.; Komatsu, K.; Xu, L.S.; Tani, T. Coumarins from the fruits of Cnidium monnieri. J. Nat. Prod. 2000, 63, 485-488.

11. Zhao, J.; Zhou, M.; Liu, Y.; Zhang, G.; Luo, Y. Chromones and coumarins from the dried fructus of Cnidium monnieri. Fitoterapia 2011, 82, 767-771.

12. Oh, H.; Kim, J.S.; Song, E.K.; Cho, H.; Kim, D.H.; Park, S.E.; Lee, H.S.; Kim, Y.C. Sesquiterpenes with hepatoprotective activity from Cnidium monnieri on tacrine-induced cytotoxicity in Hep G2 cells. Planta Med. 2002, 68, 748-749.

13. Zhou, F.; Zhong, W.; Xue, J.; Gu, Z.L.; Xie, M.L. Reduction of rat cardiac hypertrophy by osthol is related to regulation of cardiac oxidative stress and lipid metabolism. Lipids 2012, 47, 987-994.

14. Zhang, J.; Xue, J.; Wang, H.; Zhang, Y.; Xie, M. Osthole improves alcohol-induced fatty liver in mice by reduction of hepatic oxidative stress. Phytother. Res. 2011, 25, 638-643.

15. Zhao, Y.; Zhao, B. Oxidative stress and the pathogenesis of Alzheimer's disease. Oxid. Med. Cell. Longev. 2013, doi:10.1155/2013/316523.

16. Gillmore, A.; Lauret, C.; Roberts, S.M. A route to the structure proposed for puetuberosanol and approaches to the natural products marshrin and phebalosin. Tetrahedron 2003, 59, 4363-4375. 
17. Ito, C.; Matsuoka, M.; Mizuno, T.; Sato, K.; Kimura, Y.; Ju-ichi, M.; Inoue, M.; Kajiura, I.; Omura, M.; Furukawa, H. New coumarins from some citrus plants. Chem. Pharm. Bull. 1988, 36, 3805-3810.

18. Ito, C.; Furukawa, H. Two new coumarins from murraya plants. Chem. Pharm. Bull. 1989, 37, 819-820.

19. Gray, A.I.; Meegan, C.J.; O’Callaghan, N.B. Coumarins and their taxonomic value in the genus Phebalium. Phytochem. 1992, 31, 3083-3090.

20. Ito, C.; Otsuka, T.; Ruangungsi, N.; Furukawa, H. Chemical constituents of Micromelum minutum. Isolation and structural elucidation of new coumarins. Chem. Pharm. Bull. 2000, 48, 334-338.

21. Imai, F.; Kinoshita, T.; Sankawa, U. Constituents of the leaves of Murraya paniculata collected in Taiwan. Chem. Pharm. Bull. 1989, 37, 358-362.

22. Joshi, P.C.; Mandal, S.; Das, P.C.; Chatterjee, A. Two minor coumarins of Boenninghausenia albiflora. Phytochemistry 1993, 32, 481-483.

23. Garg, T.K.; Chang, J.Y. Oxidative stress causes ERK phosphorylation and cell death in cultured retinal pigment epithelium: Prevention of cell death by AG126 and 15-deoxy- $\Delta 12$, 14-PGJ2. BMC Ophthalmol. 2003, 3, 5:1-5:15.

24. Kostoryz, E.L.; Zhu, Q.; Zhao, H.; Glaros, A.G.; Eick, J.D. Assessment of cytotoxicity and DNA damage exhibited by siloranes and oxiranes in cultured mammalian cells. Mutat. Res. 2007, 634, 156-162.

25. Melnick, R.L. Carcinogenicity and mechanistic insights on the behavior of epoxides and epoxide-forming chemicals. Ann. N. Y. Acad. Sci. 2002, 982, 177-189.

(C) 2014 by the authors; licensee MDPI, Basel, Switzerland. This article is an open access article distributed under the terms and conditions of the Creative Commons Attribution license (http://creativecommons.org/licenses/by/3.0/). 